\title{
Transforming Low-Income Communities through improving the Efficiency of Architectural Energy Saving Design
}

\author{
Reham El-Dessuky Hamed, \\ Architectural Lecturer, Beni-Suef University, Faculty of Engineering, Beni-Suef, Egypt \\ R_dessuky@yahoo.com
}

\section{Abstract}

Housing problem in Egypt is an exacting problem facing all segments of society; it has accumulated over ages due to the economic, social and political conditions in Egypt since mid-twenties. By 2005, the National Housing Program (NHP) was announced, in order to accommodate the rapid population growth. However, the Governmental housing projects in Egypt did not meet all the housing requirements especially for the limited income groups either in number or quality. Whereas housing problem is not the number of units needed but also the problem of how to provide good environment respecting the social and cultural characteristics of the community. This paper aims to consider the effect of architectural design on the thermal comfort and saving energy in Building your Home project; as one of the main pivots of the National Housing Project. Research study on low-income housing experiment in New Beni-Suef City for enhancing the efficiency of architectural saving energy design with respecting economic, social, and environmental costs using Design Builder simulation software to transforming low-income housing by achieving citizen comfort and improving energy efficiency.

Keywords: Low-Income housing - Affordable social housing- Egyptian housing projects- Adaptive comfort standard- residential energy efficiency- socio-economic aspects.

\section{ملخص البحث}

يشهر العالم الان إهتماماً متزايد بقضايا البيئة، حيث بادئ البادرت العديد من دول العالم في اتخاذ خطوات عملية في سبيل توفير المأوي

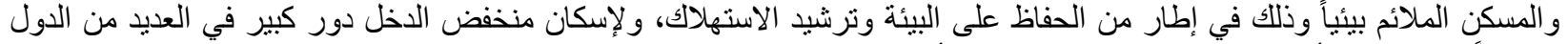

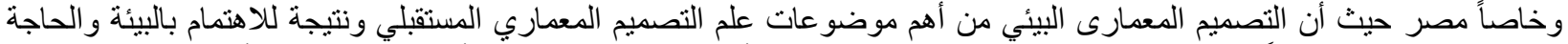

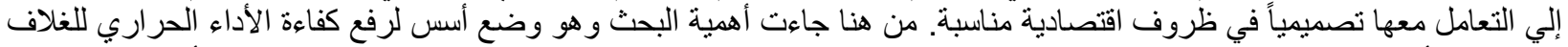

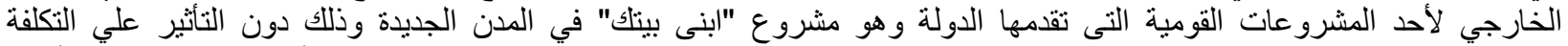

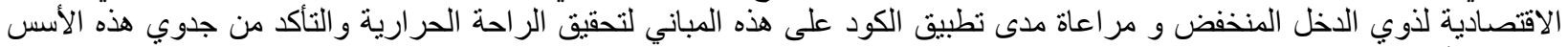

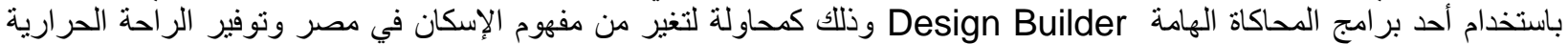
داخل المبني بجانب نوفير الاحتياج للمأوى و الامان.

\section{Introduction}

The problem of housing in Egypt is not isolated from the problems facing the social and economic development of the country. Accordingly, the government turned to the project of self-construction which Known "Building your House" as one of the national projects that introduce a solution of the problem of housing in Egypt. In contrast the project facing the random and anarchy as a result to the lack of controlling and following-up during the implementation stages, besides the contest of beneficiaries to win the land. The causes of housing problem are basically a result of many factors such as: the shortage of housing units especially for low income sectors, increasing of population growth rates, the deterioration of the existing housing stock for the lack of maintenance, rural migration to urban areas caused the uncontrolled urban growth, the shortage of money invested in low cost housing projects, 
the increase in the final cost of building due to the increase in cost of land, building materials and labor, and the lack of well-organized public participation in low cost housing. However, the main objective of building your house project is to solve one of the greatest social problems through enabling young couples to find a suitable flat at a reasonable price. But the actual situation indicates that most of housing projects do not meet all housing requirements especially for the limited income groups either in number of housing units or quality of life. Based on building your house residents' complaints," normality of designing models matchless the environmental or social conditions, therefore many modifications have been made for reaching citizen environmental and functional comfort by paying 600L.E."[1], this requires assigning specialized companies for execution and supervision to improve quality and quantity of comfort levels by avoid them to be tricked from the constructors. Study aims to concentrate on enhancing citizen comfort and improving energy efficiency, or in other words, transforming low-income housing by improving the efficiency of architectural energy saving design. Housing is NOT just a programmatic goal to be attained in a certain time plan, adequate housing must provide more than four walls and a roof; adequate housing as a component of the right to an adequate standard of living. Research problem on: Architectural design for low-income housing is not energy efficient although social housing is one of the more housing sectors that need to raise energy efficiency, reach thermal comfort and reduce costs". Causes of the problem: using the same architectural models in all cities without taking into account the environmental effects such like climate and topography as shown in [Figure1], where reflected passively in planning sites in some cities. New Beni Suef City has large problems as the disregard of citizen comfort and energy efficacy.

Figure (1) The Same Architectural Models in All Cities without Thinking in the Environmental Effects

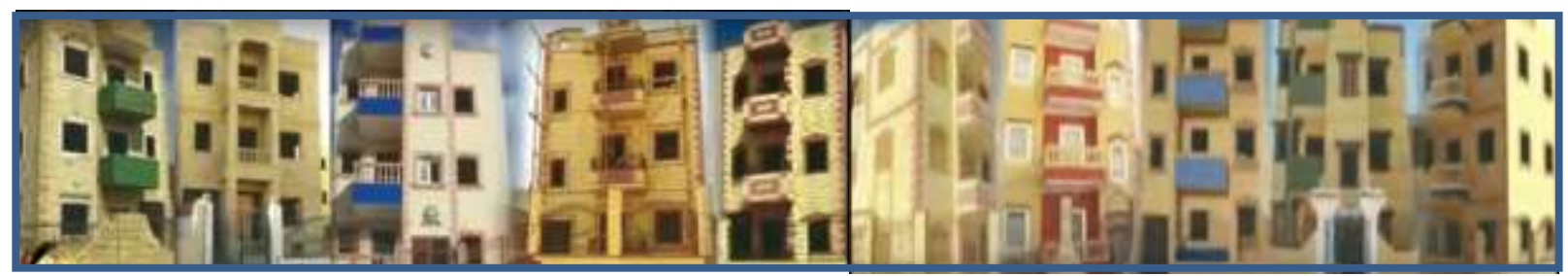

\section{The National Housing Project (NHP)}

The National Housing Project is considered to be one of the most important projects to overcome the problem of housing through the provision of adequate and appropriate housing for young people with limited income to provide 500 thousand housing units during the period of six years, this amounts to the construction of $(85,000)$ apartments per year to solve the housing problem in Egypt [2], which is one of the biggest problems facing the Egyptian citizen who dreams to have a suitable apartment with a cost matching with his level of income. In light of the Egyptian government's strategy towards providing affordable housing for low-income category to face rapid population growth and avoid building informal housing in urban areas through suggestion new social housing projects which will be established in new cities. This is done through the project of social housing, which aims at quick provision of plots for low and middle -income category who are the most important challenges facing the Egyptian society. 
Figure two represents location and percentage of building your home project throughout the Country [3], indicating the share of New Beni Suef City (shown in Red).

Figure (2) Location And Percentage Of "Building Your Home Project" Throughout the Country

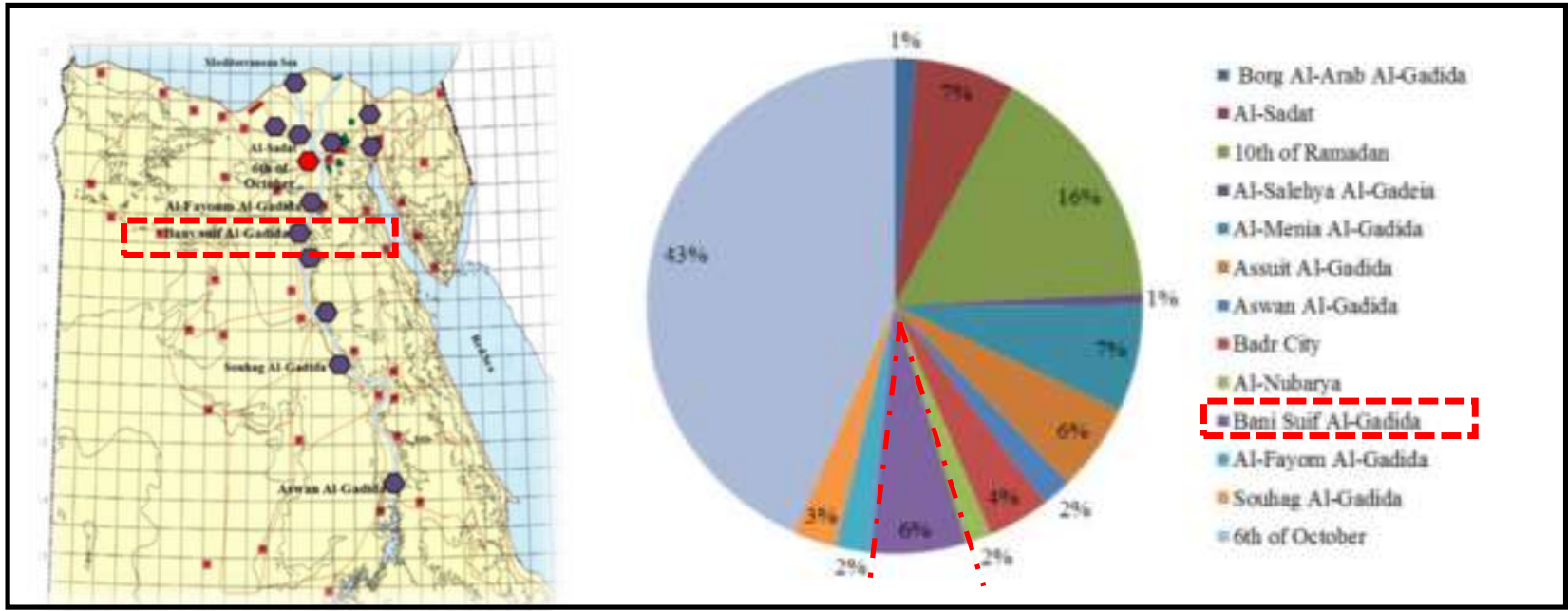

The Ministry of Housing and Urban Communities plays a major role in providing planned plots having utilities for this project. On the other hand, there is a decreasing in government funding for housing projects, especially social housing projects, therefore ministry of housing is looking for alternative sources of funding such as public-private partnership approach (PPP) to reduce the government financial allocation for housing projects and get a benefit from Previous successful experiences of private sector in this field [4]. It has been known that the housing process is divided into different steps: decision making, planning, design, implementing, controlling and maintenance. Community participation could be activated in one or more of these steps: So whenever the more participation in these steps, the more reduction in the total cost of housing is realized. It depends on the form of participation which is affected by the social and cultural characteristics of the community. Ministry of Housing on 2005 has announced that there are seven types of projects as shown in the following table (1). [5]

Table (1) The Seven Types of the National Housing Project (NHP)

\begin{tabular}{|l|l|c|l|}
\hline Project type & \multicolumn{1}{|c|}{ Project Characteristics } & Proposed housing units & Area \\
\hline First type & Provision of titling system for housing units & 327141 & $63 \mathrm{~m}^{2}$ \\
\hline Second type & $\begin{array}{l}\text { land granting for low-income people to build their } \\
\text { housing themselves (Ebni Betak project) }\end{array}$ & 93756 & $150 \mathrm{~m}^{2}$ \\
\hline Third type & Land sale for investors to build housing units & 85050 & $63 \mathrm{~m}^{2}$ \\
\hline Fourth type & $\begin{array}{l}\text { Bet al aliyah project and provision of titling system } \\
\text { for housing units }\end{array}$ & 3020 & $42 \mathrm{~m}^{2}$ \\
\hline Fifth type & Awla bel re'aya" project & 28294 & $63 \mathrm{~m}^{2}$ \\
\hline Sixth type & providing rental system for housing units & 37807 & $63 \mathrm{~m}^{2}$ \\
\hline Seventh type & providing titling system in desert & 14563 & \\
\hline & & &
\end{tabular}


While Building your house project (the second type of projects) is considered one of the most important projects which are carried out in the frame of solving part of the problem of limited in come people. It is considered one of the giant projects which the government adopted it regardless the problem or economy of citizen, the aiming class of the project as following table.

Table (2) The Aiming Class of the National Housing Project (NHP) [6]

\begin{tabular}{|l|l|}
\hline Age & From 21 to 40 year \\
\hline Income & Not more 1000 L.E. for single and for the family 1500. \\
\hline Living place & According to the zone of the project \\
\hline Reservation & The applicant doesn't benefit before from the supporting of government. \\
\hline Specialization: & For himself not behalf.
\end{tabular}

Planning of the project is contracted with ministries for planning, preparing drawings, and making urbanely models; where the project adapted the concept of the stage building as the benefit builds his house on stages according to his needs to take the support of money on stages with the developing of building and finishing work. Besides exemption the benefits of the project from paying the rest of credits from the price of the plot, according to building of three floors and indoor / outdoor finish [7]. The aiming of the project is reducing cost of housing unit on the state and gives the chances for limited income people for participation of housing through bearing the responsibility of building from the drawings and the conditions which the state put them. Housing style main concept is based on specialized plot of housing in different new cities its area $150 \mathrm{~m}^{2}$ and saving all facilities, permitted construction rate is $50 \%$. Land plots have been divided into $(8.60 \times 17.5 \mathrm{~m}$.) and the majority of the models are connected from both sides with no side-impact, with the semi-attached model used in the terminal as shown in fig (3).Blocks consist of plots arranged back to back were homes are attached side by side. Each home has a front and back yard. Each of the back and front yards ranges between 3.5 to 4.0 meters. [3]

Figure (3) Housing Style of Building Your Home Project in the New Cities
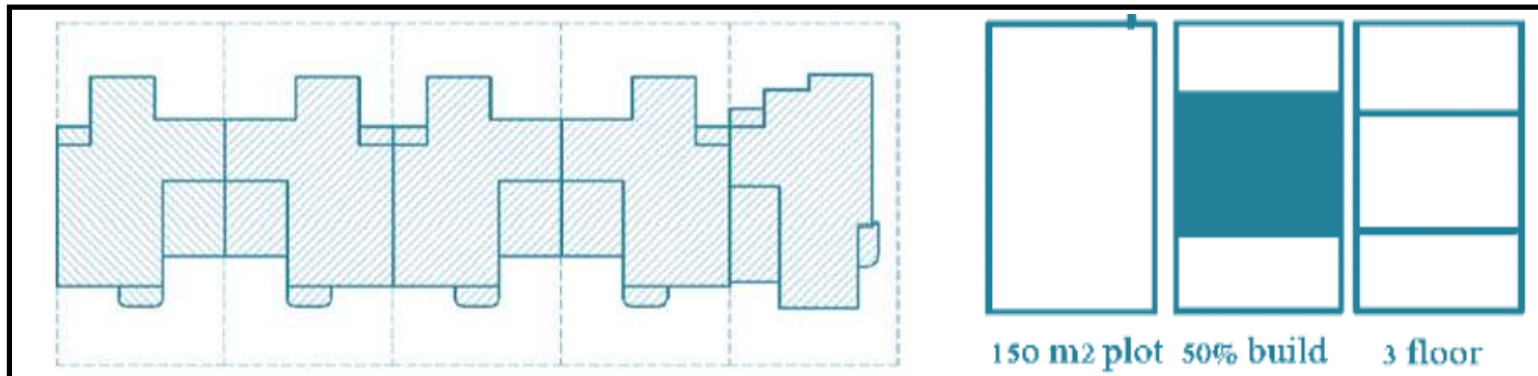

House consists of a ground floor and two upper floors built with governmental financial support depending on the construction stages. The plots are with on front side and three neighbors. Citizen doesn't choose where his plot is or what is the model of housing, but this is done by lottery. The flat consists of only two rooms, hall and facilities that not exceed the total of building area more than $63 \mathrm{~m}^{2}$; it is also worth mentioning the incomplete stairs to reduce the costing although they need to use the roof as shown in [Figure 4]. More than 90,000 plots of land were distributed in 34 new cities in 13 cities as following: 6th of October, 10th of Ramadan, New Salhiya, Nubaria, Sadat, Badr, New Burj Al Arab, New Fayoum, New Beni Suef, New Minia, New Assiut, Sohag and New Aswan. [5] 
Figure (4) Program Models of Building Your Home Project (Ground Floors)

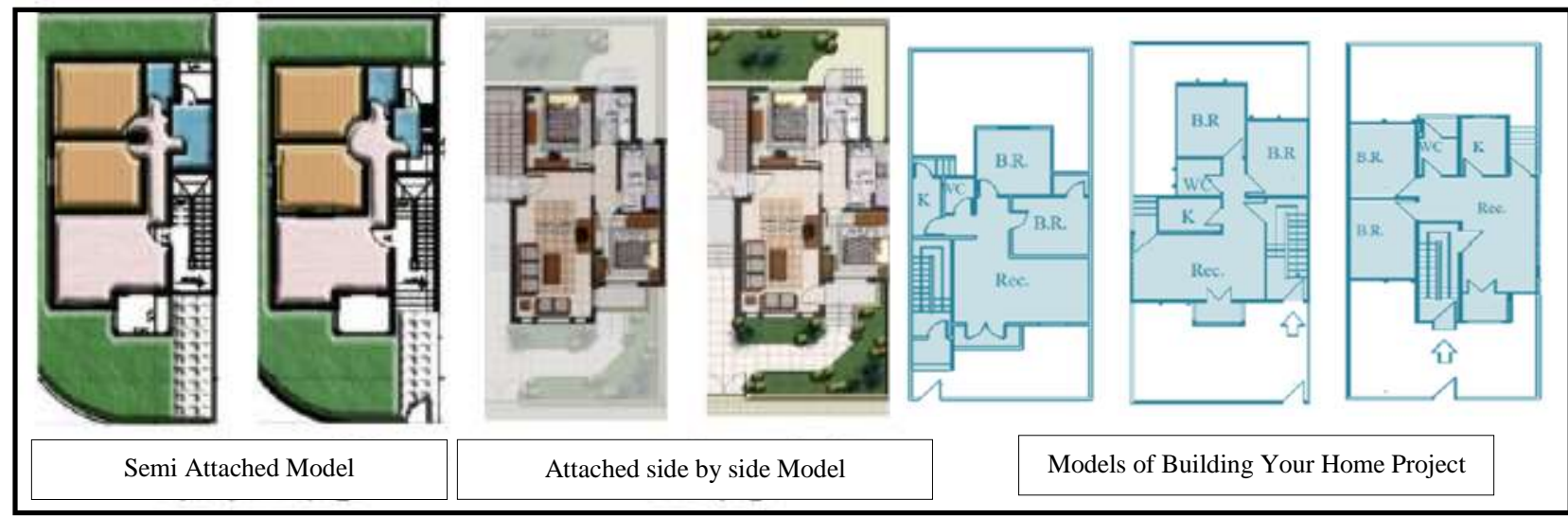

The planning process and the architectural procedures are both based on the socio-economic aspects involving community participation. This means that community participation is an important part in both the planning and architectural process. On the other hand, community participation in improving the existing housing stock or in the building of new dwellings requires special consideration which eventually affects the building industry including building materials and methods of construction. This is the base for the use of the appropriate technology which is appropriate for community participation. The factors influencing the economics of residential unit design are noteworthy on (blocks form, units' area, height surveys, number of floors, spaces distribution, circulation elements, implementation stages, construction system, building materials and finishes.

\section{The Problem of Housing in Egypt}

Housing in Egypt is not isolated from the problems facing the social and economic development and technical aspects, where the most visible symptom of Egypt's urbanization problem has been the lack of low-income and social housing available across the country. The country suffers from a fundamental mismatch represented in the gap between supply and demand. More than 11 million people live in informal slum settlements, besides $90 \%$ of Egypt's housing is built informally and $10 \%$ is built by professional companies. Unfortunately, construction companies are building new homes primarily for the high-income market for the sake of profitability. In the experience of building your home project, the population role is limited to build for the government its project -which is rubber stamped in all of its detailseven the extension of core house should be according to a pre-determined plan. Community participation may be a way of making a project acceptable to the local population, as it will be cheaper and smoother to implement. From the residents point of view it means a role in the development of their environment where they can choose the improvement option, and reduce the project costs. Questionnaire [Table3] was designed to evaluate the Housing Situation comfortable for low-income citizen. 
Table (3) An Assessment of the Housing Situation comfortable For Low-Income People

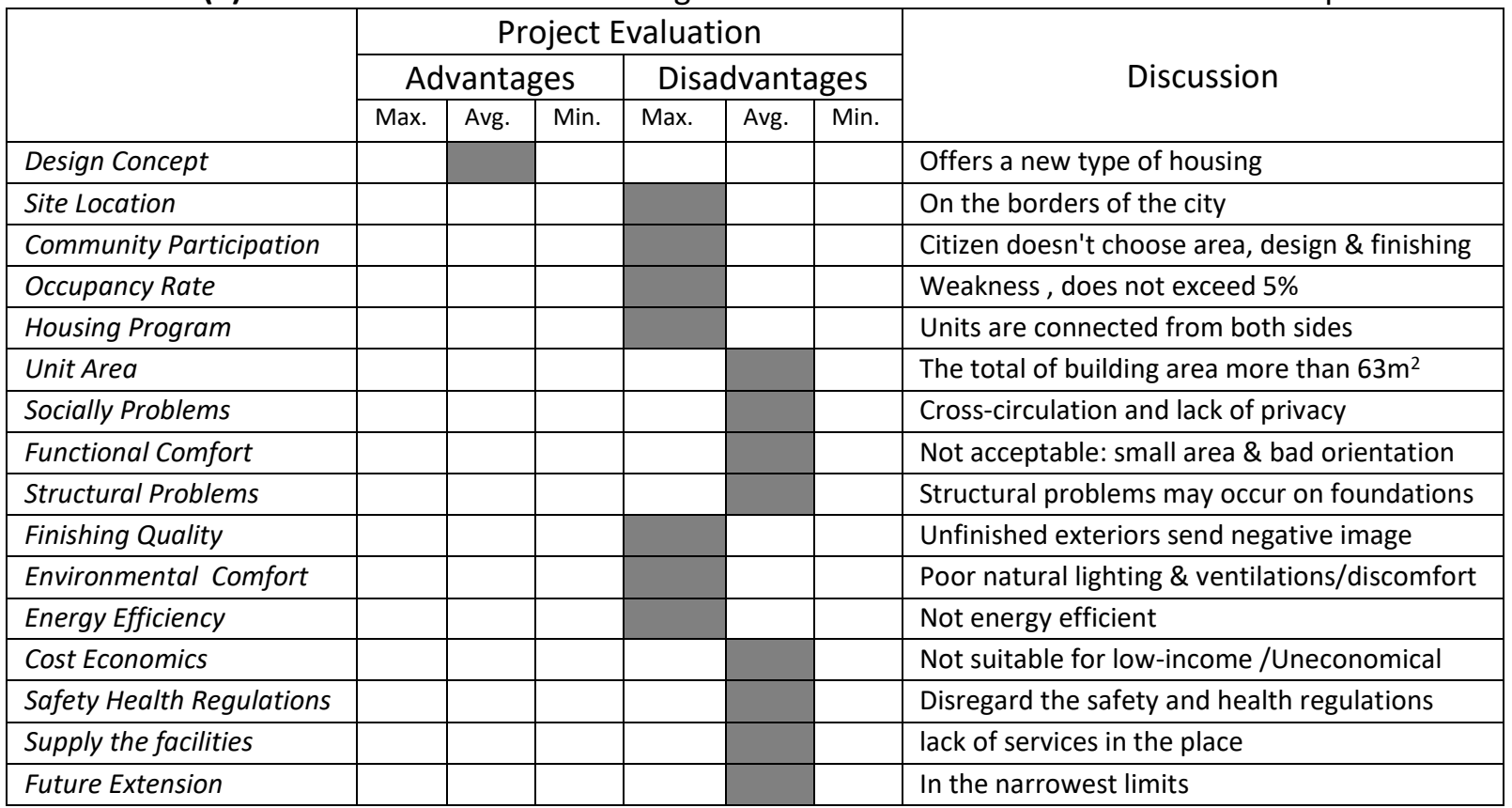

Accordantly, the main concept of project is to make the effective role of housing participation; definitely citizen are hoped and considered the best future and life about the idea of building house for each youths and family, the government paved the hopes for the citizens but they got into a lot of problems and troubles, which can be summarized in the following: Administratively (unstructured management, lack of communication between different departments, Absence of censorship putting complex conditions for getting license and there are more expenses). Socially (the project became Typical away from identity \& cultural society, project doesn't represent certain community class). Community participation (Citizen doesn't choose area, design \& finishing). Environmentally (No consideration to choosing sites, orientation, climate and topography, poor natural lighting \& ventilations, feeling discomfort, absence guidance signs). Design Concept (The same models in all cities without considering climate \& topography, design don't represent identity and culture benefits, bad planning. No green areas or other community facilities, few rooms, narrow spaces, incomplete stairs, fixed paints color and material, absence of security, privacy \& flexibility and lack of beautiful features). Executional disadvantages (Serves aren't available; lack of infrastructure a lot of sites need soil replacement, absence of transportation means). Economically (mismatches between demand \& supply, raises of prices, increase in burden on the owner, loans aren't suitable). According to the New Urban Communities Authority (NUCA) and the ministry of housing [8], the project aimed at enhancing the participatory role of the users. Therefore, it is necessary changing the policies should start from the level of urban planning of new cities, by first studying the social norms and the people's needs before deciding on the land areas and height restrictions. Increasing the area of building to reach $60 \%$ instead of $40 \%$ to reach $90 \mathrm{~m} 2$ at least and the rest is the green area as it is planned for it. Giving the citizen the freedom to choose his elevation which would suit the general taste and specialized fixed colors light beige or grey. 
Residential energy efficiency offers untold potential for savings, job creation, improvements in health and safety, and community reinvestment. But often, the people who would benefit most from energy upgrades are least able to afford them.

\section{The Egyptian Residential Buildings Energy Code (ERBEC)}

Energy Codes as Strategy for Energy Efficiency in Buildings became the more important in residential efficiency policies for controlling architecture design and providing energy efficiency; form the architectural design base to evaluate the building energy performance and develop energy efficiency programs. There are three approaches of building energy codes [9]: Prescriptive Approach; prescribes the minimum requirements for achieving thermal comfort and energy efficiency. ERBEC contributes lists the required minimum R-value or maximum $U$ factor for the building envelope elements (windows, walls and roof). Also building lighting systems prescriptive approach lists for different building type the allowable watts for each metric square. For mechanical equipment and systems prescriptive approach lists the minimum required equipment efficient. Therefore, prescriptive approach considered the simplest, quick and easy to use, but it may be restrictive for several limitations and constrains. However, this approach applied in the countries which have no experience in thermal regulation. Then Adjustment Approach: allows to increasing energy efficiency rates in one element of the main building systems (building envelope, lighting system and mechanical systems) against decreasing it in another. For example, in some cases it's necessary to decrease wall efficiency (low R-value) for increased window efficiency (low U-factor), as well increasing roof insulation for decrease or remove slap-edge insulation. For lighting systems, it depends on the trade-off between wattages of proposed lighting in different spaces. While the only tool allowed for mechanical equipment and systems, is toward choosing higher cooling equipment efficiency for achieving economized requirement. Adjustment approach is less restrictive than prescriptive approach because it describes the actual building design and it could adjust each building element individually. This approach allows for designer to reduce energy efficiency in an element as long as the energy efficiency of other elements is increased to compensate the reduction. Performance Approach: compares the proposed design with the reference design and demonstrates that the proposed design efficiency is at least as the reference design in the annual energy use. It allows the maximum flexibility but it may require more effort. Performance approach is the only approach that can be used to show energy compliance when using nontraditional and unusual building elements and features. It is the most in time consuming in the three approaches. It also allows the most flexibility because it evaluates the whole building not only its elements. And takes in consideration many more variables (windows, orientation and shading), which affect energy efficiency by using acceptable simulation tools such as: DOE-2 and Energy Plus.

\section{Low-income Housing Design with Comfort and Energy Efficiency}

Architectural design for low-income housing is not energy efficient although, social housing is one of the more housing sectors that need to raise energy efficiency, reach thermal comfort and reduce costs. Low-income households typically face the greatest energy burden Where 
Families in these communities often live in older homes that lack adequate insulation and energy-efficient appliances. It is worth mentioning that low-income families spend more than 17 percent of their incomes on household energy; while other households spend on average just 4 percent [10]. Most energy efficiency benefits do not reach this population, and more attention must be given to support the energy needs of distressed communities. Energyefficient social housing benefits low-income households by reducing energy bills and the environment by reducing causes of energy consumption - It creates a thread through general issues of energy conservation and affordable housing - so that those households can better afford the necessities of life. Designing energy efficient affordable housing is especially complex because of the limited budget available for "special" features, the tight timelines. To be affordable housing must be designed and constructed to last and not require expensive maintenance; energy efficient construction improves building durability by reducing moisture related problems; when families spend less on energy bills; they can afford a better budget for maintenance and repairs [11]. While architectural consideration for affordable and energy efficient housing depends on planning efficient land use, achieving design standards, considering building orientation, using passive ventilation techniques, designing appropriate window sizing and placement. Besides encouraging the use of energy saving technologies via using light-emitting diodes (LED), air conditioning exchangers (HVAC) and biogas in the proposed affordable energy efficient housing for low income community [12]. Low-income housing design with comfort and energy efficiency requires selecting the most cost-effective and energy efficient package of measures which means choosing measures that are not "best" in their category. So it is worth mentioning that Factors affecting on architectural concepts can be divided into physical and unphysical factors. Physical factors refer to building elements. Building shape (form, area and height), Skyline: (straight or complicate), Landline: (straight, inclined, regular, irregular, or reflected), Visual features: (unity, proportions, balance, harmony, texture and color), Natural Elements: (topography, slopes, trees, plantations, water sources, stones and climate factors). Urban Characteristics :( site organizing, type of urban space, streets, relation between blocks and connecting spaces). User's Needs (shelter, security, protection, activities, privacy, and comfort), Indoor Environmental Quality: (Thermal, Lighting, Ventilation, Acoustics, Humidity, Vibration, and Odor).Environmental Control: (architectural identity, solar radiation, thermal mass, heating and cooling, insulation, natural lighting, natural ventilation, HVAC, and climate control tools) besides, Energy Performance: (Consumption, Saving, producing, and recycling)].While Non-physical factors, refer to cultural background, aesthetic values, social values, personality, public taste, spiritual interests, environmental identity and users comfort[13]. Accordantly, low-income housing design with comfort and energy efficiency principles based on achieving the highest performance of the residential unit while respecting economical aspects, contributes equally between comfort, cost and time . Functional performance is not intended only but the overall of (environmental- technical and economical); so as to get the best performance and that is not suitable at a higher cost, but at the lowest cost in accordance with the appropriate period of time. Transform Housing \& Support helps citizen to reach their goals and live independent and fulfilling lives. 


\section{An Outline of the Field Investigation}

New Urban Communities Authority (NUCA) was established according to law 59/1979 aiming to: creating new civilized centers for achieving community stability and economic prosperity, redistribution of inhabitants far from the Nile valley, developing new attraction areas beyond the existing cities and villages, and extend the urban axis to the desert and remote areas to decrease the Urban extension on the agricultural lands. NUCA assures on the availability of housing units for the low Incomes, aiming to raise the standard of living for this level. it has launched several effective housing projects that suits the different levels and with many facilities, and to continue the strategic plan of the New Urban Communities, the most appropriate sites have been chosen for the new cities with different economical basis such as New Beni Suef City where was established by Cabinet decree (643/1986). As a part of the Social Housing Project in New Beni Suef city on December of 2015; the total number of housing is 16.599 units distributed as follows: 5848 unit implemented by (NUCA), 4080 social housing units by NUCA and 1224 housing units which are being implemented by New Urban Communities Authority within Social Housing Project. Referring to build your own house project, the total number of plots in the city is 5975 plots (3298 plots in the first district and 2677 plots in the second)as shown in [Figure 5] [14].

Figure (5) Location of build your own house project in New Beni Suef City

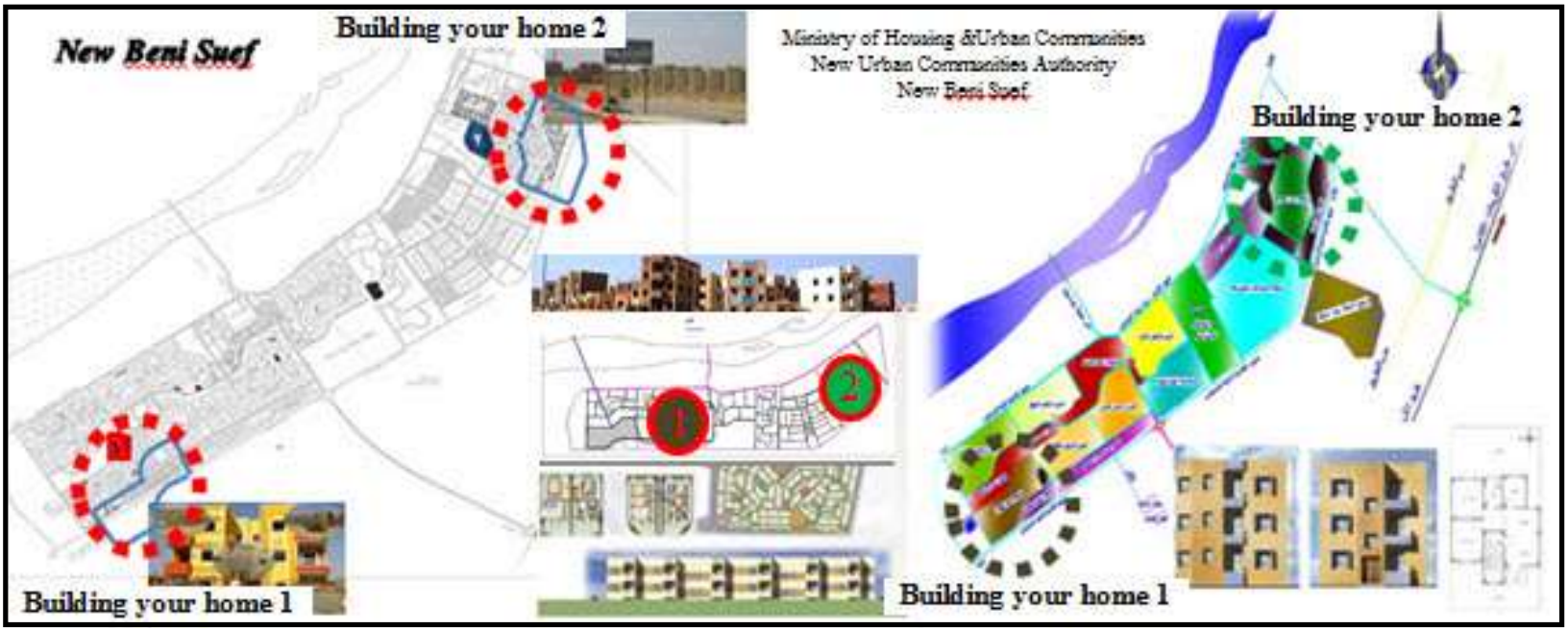

The Location Land uses display the complete separation between uses which in turn led to an absence of mixed uses; therefor citizens transformed some of residential units use to mixed use for providing the lost services. As for, the monolithic residential land Characterized in harmony with the surrounding urban tissue despite the lack of green areas and facilities. Analysis of whole uses segregation requires long walking distances to daily needs, which is not consistent with the nature of the region community. It can be observed that many of the plots have at least 1 floor which means that the project policy succeeded, when it stated that the land will be taken from the household if he/she doesn't complete the first floor within the first year. Few blocks finished construction and completed the three floors so as to be exempted from the rest of the premiums. Blocks consist of plots arranged back to back were homes are attached side 
by side. Each home has a front and back yard. Each of the back and front yards ranges between 3.5 to 4.0 meters. This means that a total setback between buildings from their back sides ranges between 7.0 to 8.0 meters, while on their completion; they will be about 12.5 meters high. These long narrow double backyards actually will not provide enough privacy, thermal comfort, natural lighting and ventilation. Research study on low-income housing experiment in New Beni-Suef City for enhancing the efficiency of architectural saving energy design while respecting economical, social, and environmental costs using Design Builder simulation software to transforming lowincome housing by achieving the citizen's comfort and improving energy efficiency, simulation tool for checking building energy,

Figure (6) Energy Modeling Methodology

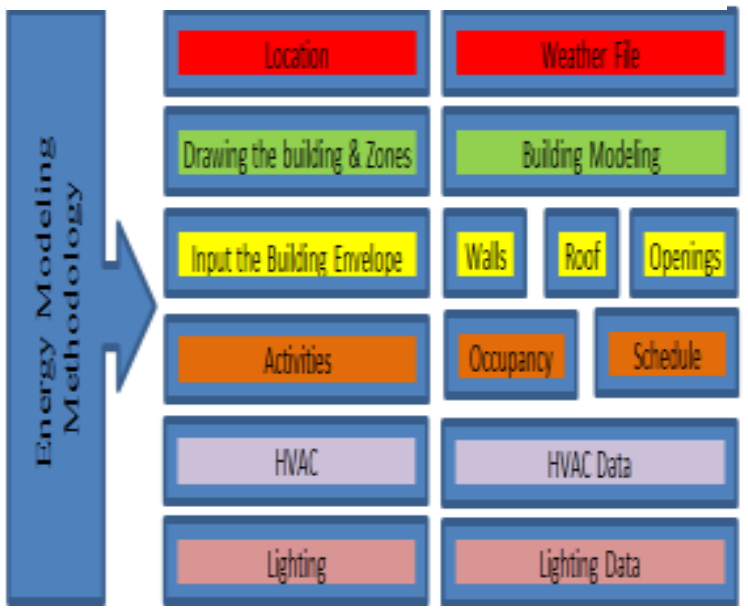
carbon, lighting and comfort performance. Developed to simplify the process of building simulation as shown in [Figure 6], it allows a rapid comparison between function and performance of building designs in order to deliver results on time and on budget. [15]

\section{8- Stages of Increasing Architectural Design to Provide Energy Efficiency:}

Building design tools are performed to analyze the energy performance of a building and to understand the relationships between the design parameters and climatic characteristic of the site, and energy use characteristics of the building. The effects of all kinds of changes can be simulated in a fraction of time and with a fraction of cost it would take to be studied in real life.

Figure (7) Stages of Increasing Architectural Design \& Energy Efficiency

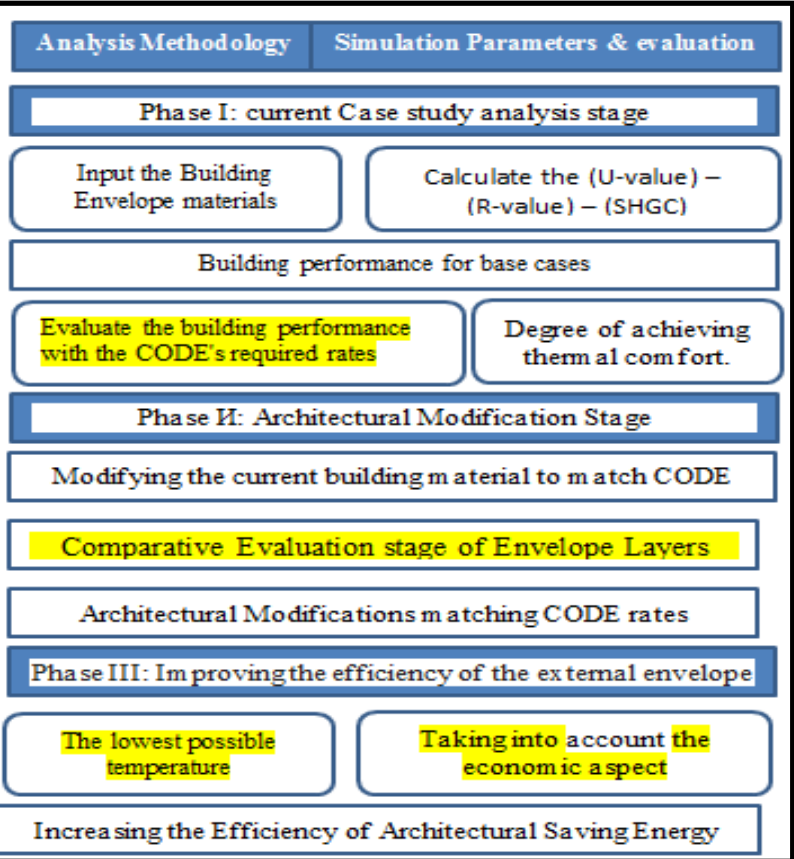

In practice, simulation tools can be utilized for the following functions: evaluate design

options and investigate design optimization, facilitate the investigation of new ideas, check compliance with building energy codes, and determine the impact of energy conservation measures.

The methodology implemented in this paper was divided into three stages shown in [Figure 7]. First: Analysis of Energy Performance for Base Case (inputs building envelope materials for walls, roof and openings), then calculate U\&R Values for the envelope, and Solar Heat Gain Coefficient (SHGC) for openings. Result of this stage indicates the building performance of base case. Second: Architectural Modification Stage (envelope layers modifications with economic aspect), then the 
comparative evaluation stage of envelope layers modifications. Results of this stage indicate the architectural modifications matching CODE rates. Third: improving the efficiency of the external envelope.

\section{Phase I: current Case study analysis stage:}

Program Inputs of the sample in the current situation: input the site weather file, drawing the building in the program (zone $\backslash \mathrm{s}$ ), and Input the Building Envelope materials, to calculate the (Rvalue, U-value, and SHGC) as shown in [Table 4]. Buildings specs are: without air conditioning color of the facades is light yellow- \% openings in all façades (10-20\%).

Table (4) Phase I: Current Case study analysis stage

\begin{tabular}{|c|c|c|c|}
\hline \multicolumn{4}{|c|}{ Phase I: current Case study analysis stage } \\
\hline $\begin{array}{l}\text { Building } \\
\text { Envelope }\end{array}$ & External Walls & Roof & Openings \\
\hline $\begin{array}{l}\text { Material } \\
\text { Layers }\end{array}$ & $\begin{array}{l}2 \mathrm{~cm} \text { Cement Plaster } \\
12 \mathrm{~cm} \text { Red Brick }-2 \mathrm{~cm} \\
\text { Cement Plaster }\end{array}$ & $\begin{array}{l}2 \mathrm{~cm} \text { cement plaster }-15 \mathrm{~cm} \text { R.C. }-2 \mathrm{~cm} \text { bitumen } \\
\text { insulating two layers }-5 \mathrm{~cm} \text { Plain } / \text { tendencies } \\
\text { Concrete }-5 \mathrm{~cm} \text { sand }-2 \mathrm{~cm} \text { cement mortar- } 2 \mathrm{~cm} \\
\text { cement tiles }\end{array}$ & $\begin{array}{c}\text { Painted wooden } \\
\text { window frame - } \\
6 \mathrm{~mm} \text { Single Clear Glass }\end{array}$ \\
\hline R-Value & 0.339 & 0.421 & 0.175 \\
\hline U-Value & 2.944 & 2.373 & 5.714 \\
\hline SHGC & ------- & ------ & 0.820 \\
\hline
\end{tabular}

Evaluate Building Performance with the CODE's Required Rates by comparing results of the building envelope simulation with Code values to evaluate the current design as shown [Table 5]

Table (5) Compare the Results with the Values of the Egyptian Code and the SHGC

\section{Compare the results with the values of the Egyptian code and the SHGC}

\begin{tabular}{|c|c|c|c|c|c|c|c|c|c|c|}
\hline \multirow{3}{*}{$\begin{array}{l}\text { Location } 1 \\
\text { R-Value } \\
\text { Egyptian } \\
\text { code }\end{array}$} & \multicolumn{5}{|c|}{ Model (North/ South) } & \multicolumn{5}{|c|}{ Model (East / West) } \\
\hline & \multicolumn{2}{|c|}{ Walls } & Roof & \multirow{2}{*}{\multicolumn{2}{|c|}{$\begin{array}{c}\text { Openings } \\
10<0<20 \%\end{array}$}} & \multicolumn{2}{|c|}{ Walls } & Roof & \multirow{2}{*}{\multicolumn{2}{|c|}{$\begin{array}{c}\text { Openings } \\
10<0<20 \%\end{array}$}} \\
\hline & $\begin{array}{c}N \\
0.69 \\
\end{array}$ & $\begin{array}{c}S \\
0.70\end{array}$ & 2.80 & & & $\begin{array}{c}E \\
0.90 \\
\end{array}$ & $\begin{array}{c}W \\
0.90 \\
\end{array}$ & 2.80 & & \\
\hline Base Case & \multicolumn{2}{|c|}{0.339} & 0.421 & \multicolumn{2}{|c|}{0.820} & \multicolumn{2}{|c|}{0.339} & 0.421 & \multicolumn{2}{|c|}{0.820} \\
\hline SHGC & \multicolumn{2}{|c|}{----- } & ------- & $\begin{array}{c}\mathrm{N} \\
\text { Not } \\
\text { required }\end{array}$ & $\underset{\substack{\text { Not } \\
\text { required }}}{S}$ & \multicolumn{2}{|c|}{------ } & ------- & $\begin{array}{c}E \\
0.7\end{array}$ & $\begin{array}{l}W \\
0.7\end{array}$ \\
\hline $\begin{array}{l}\text { Compare } \\
\text { Values }\end{array}$ & \multicolumn{5}{|c|}{$\begin{array}{l}\text { The values of thermal resistance are lower than } \\
\text { the values of the code. SHGC is not required as } \\
\text { Code rates }\end{array}$} & \multicolumn{5}{|c|}{$\begin{array}{l}\text { The values of thermal resistance are lower than } \\
\text { the values of the code. SHGC is larger than the } \\
\text { required values }\end{array}$} \\
\hline Location 2 & \multicolumn{5}{|c|}{ Model(North/East) \& Model(North/West) } & \multicolumn{5}{|c|}{ Model(South/East) \& (South/West) } \\
\hline R-Value & \multicolumn{2}{|c|}{ Walls } & Roof & \multicolumn{2}{|c|}{ Openings } & \multicolumn{2}{|c|}{ Walls } & Roof & \multicolumn{2}{|c|}{ Openings } \\
\hline $\begin{array}{l}\text { Egyptian } \\
\text { code }\end{array}$ & $\begin{array}{c}\text { NE } \\
0.80\end{array}$ & $\begin{array}{l}\text { NW } \\
0.80\end{array}$ & 2.80 & \multicolumn{2}{|c|}{$10<0<20 \%$} & $\begin{array}{c}\text { SE } \\
0.80\end{array}$ & $\begin{array}{l}\text { SW } \\
0.80 \\
\end{array}$ & 2.80 & $10<0$ & \\
\hline Base Case & \multicolumn{2}{|c|}{0.339} & 0.421 & \multicolumn{2}{|c|}{0.820} & \multicolumn{2}{|c|}{0.339} & 0.421 & \multicolumn{2}{|c|}{0.820} \\
\hline SHGC & \multicolumn{2}{|c|}{----- } & ------ & $\begin{array}{c}\mathrm{NE} \\
\text { Not } \\
\text { required }\end{array}$ & $\begin{array}{c}\text { NW } \\
\text { Not } \\
\text { required }\end{array}$ & & & ------- & $\underset{\text { Not required }}{\mathrm{SE}}$ & $\begin{array}{c}\text { SW } \\
\text { Not required }\end{array}$ \\
\hline $\begin{array}{l}\text { Compare } \\
\text { Values }\end{array}$ & \multicolumn{5}{|c|}{$\begin{array}{l}\text { The values of thermal resistance are lower than } \\
\text { the values of the code. SHGC is not required as } \\
\text { Code rates }\end{array}$} & \multicolumn{5}{|c|}{$\begin{array}{l}\text { The values of thermal resistance are lower than } \\
\text { the values of the code. SHGC is not required as } \\
\text { Code rates }\end{array}$} \\
\hline
\end{tabular}


Analysis of The Simulation Outputs: Outputs of simulation analysis of current cases evaluate temperature and Heat Gain/Loss analysis for each zone inside the building, in order to reach thermal comfort guided through the average value of the Predicted Mean Vote (PMV). This refers as a thermal scale according to ASHRAE specifications. As most residential units are oriented to (North/ South) and Model (East / West), an analysis of these models was carried out.

Model (East / West): Through studying the lowest and highest Zone's temperatures in the hottest and coldest days, it was found that, living room at the second floor Western façade reached its highest temperature of $36.5^{\circ} \mathrm{C}$ because of the western orientation of the external wall and having openings in the west, while other zones reached temperatures range from 33$34.5^{\circ} \mathrm{C}$, while the bed rooms at second floor reached its lowest temperature of $8^{\circ} \mathrm{C}$ although there are eastern openings because of external wall face more than one orientation (north, east, and south) which had the greatest impact, while other zones reached temperatures range from $12-21^{\circ} \mathrm{C}$. And by comparing these results as recommended with the Egyptian code to achieve thermal comfort in the space, temperature must range between $21.8-30^{\circ} \mathrm{C}$. this confirms that this space is a bit far of thermal comfort and it needs treatments in winter, and the need for some minor changes in summer. While average value of PMV throughout the day reached ranges from 2.25-2.7 at summer, take into consideration living room at the second floor facing higher temperature than other zones(sensation scale very hot), then the bed rooms in the same floor. At winter, it was shown that most of zones located in the comfort zone, the evaluation indicator ranges between 0.7-0.16 (sensation scale Neutral and slightly cool). Bed rooms are considered the coldest zone reached 0.7 (sensation scale slightly cool).

Model (North/ South): Through studying the lowest and highest Zone's temperatures in the hottest and coldest days, it was also found that, bed rooms at the second floor reached its highest temperature of $34.5^{\circ} \mathrm{C}$ although facing the northern orientation because of the multi orientations of the external wall (north-east and west), then the living room at the same floor for the south orientation reached $34^{\circ} \mathrm{C}$. while other zones reached temperatures that range from $31-33^{\circ} \mathrm{C}$.Also bed rooms at second floor reached its lowest temperature of $16^{\circ} \mathrm{C}$, while other zones reached temperatures range from $17-21^{\circ} \mathrm{C}$. And by comparing these results as recommended with the Egyptian Energy Code to achieve thermal comfort in the space, temperature should range between $21.8-30^{\circ} \mathrm{C}$. This confirms that this space is a bit far of thermal comfort and it needs treatments in winter and some minor changes in the summer. While average value of PMV throughout the day reached ranges from 2.0-2.75 at summer, take into consideration bed rooms at the second floor facing higher temperature than other zones(sensation scale very hot), then living room in the same floor. At winter, it was shown that most of zones located are in comfort zone the evaluation indicator ranges around 1.0-0.7 (sensation scale slightly cool). Bed rooms are considered the coldest zone that reached 0.8 (sensation scale slightly cool).

Analysis of PMV for Two Models throughout the Year: Models values of feeling comfortable are not compatible with recommended indicators of PMV, especially from May to October where the highest value in July and August, while throughout the year it is located in comfort 
zone. Where all zones are located in neutral sensation, Bed rooms are considered the coldest zone reached 0.7 (sensation scale slightly cool), as shown in [Table 6].

Table (6) Analysis of PMV for two models throughout the year

\begin{tabular}{|c|c|c|}
\hline Model (East / West) & Model (North/ South) \\
\hline & Models values of feeling comfortable are not compatible with recommended indicators of PMV \\
\hline
\end{tabular}

Temperature Analysis throughout the Year: It is worth mentioning that the maximum temperature values have exceeded thermal comfort standards from May to reach the highest temperature values in July and August and then gradually decreasing on October throughout the year for the two models, as shown in [Table 7]

Table (7) Temperature Analysis throughout the Year

\begin{tabular}{|l} 
Model (East / West) \\
\hline \\
$\begin{array}{l}\text { Maximum temperature values have exceeded thermal comfort standards from May to reach the highest } \\
\text { temperature values in July and August and then gradually decrease on October throughout the year }\end{array}$
\end{tabular}

Heat Loss and Gain Analysis: Regards to [Table 8], Heat Gains (above zero level) its highest cause is Direct Solar (Yellow color) with percentage of $62.3 \%$ due to facing east and west orientation, Followed by $27 \%$ from Internal Heat Transfer (Blue color) this is due to thermal infiltration of the increased openings proportion, and 7\% of air movement (Sol Air) (Dark Green color), this is due to the building's longest side orientation to the east-west axis. And for Hourly Heat Losses (under zero level) its highest cause is due to building envelope Conduction (Red color) equals 61\%, and Inter-Zonal (Light Blue color) causes $32 \%$ this is due to the pressure difference on the façade. 
Table (8) Heat Loss and Gain Analysis

\begin{tabular}{|l|l|}
\hline Model (East / West) & Model (North/ South) \\
\hline
\end{tabular}

Adaptive comfort standard in order to evaluate the measurement data with comfort temperature. Also, ASHRAE standards to understand the maximum and acceptable humidity values in an indoor environment. The northern direction has the lowest values for indoor temperatures in summer, while for winter; the southern direction indicates the highest temperature values. It was found that the southern orientation recorded the highest thermal comfort because of the high temperature in winter and lowest in summer.

\section{Phase И: Architectural Modifications Stage:}

In this stage architects can make architectural modifications in their design in a Current Building case. These modifications can be followed by the same steps of the analytical work stage (based on building envelope layers modifications with regards to the economical aspect). Then a comparative evaluation stage can be done at the end to compare the results obtained to evaluate the degree of the success, and define if it still needs some more modifications for matching the Energy Code rates. As shown with [Figure 8], there are many building envelop treatments selected based on surfaces most exposed to the sun's radiations which are inferred from the analysis of the solar Radiation on the surfaces. Such as: changing the thickness of the wall to $25 \mathrm{~cm}$, two wall skins of thickness $12 \mathrm{~cm}$ for each \& an air gab inbetween, and using multiple thickness of expanded polystyrene (EPS) for the roof insulating. The $U$-values which the program calculated for the current case are all out of the codes rates in the total building envelope elements (walls, roof and

Figure (8) Architectural Modifications Stage

\section{Architectural Modifications Stage}

Envelope Layers Modifications with Economic Aspect

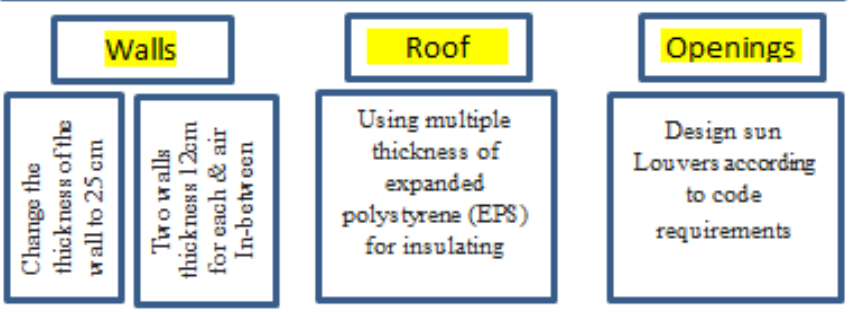

Comparative Evaluation stage of Envelope Layers

Architectural Modifications matching CODE rates 
windows), that requires a change in the building envelope layers to achieve the values stated in the CODE.

Architectural Modifications of Walls: By comparing the R-values of the building envelope with the Energy CODE rates, the exterior wall sections must be from a material that losses heat slowly in order to treat the rates of thermal conductivity to the outside at night. And the building external walls will be modified as follows:

Table (9) Architectural Modifications Stage

\begin{tabular}{|c|c|c|c|c|}
\hline \multicolumn{5}{|c|}{ Architectural Modifications Stage } \\
\hline $\begin{array}{l}\text { Architecture } \\
\text { Modifications } \\
\text { of Walls }\end{array}$ & $\begin{array}{c}\text { Wall } \\
\text { thickness } \\
25 \mathrm{~cm}\end{array}$ & $\begin{array}{c}\text { Wall thickness } 12 \\
\mathrm{~cm} .+5 \mathrm{~cm} \text { air }+ \\
\text { Wall thickness } 12 \\
\mathrm{~cm}\end{array}$ & $\begin{array}{l}2 \mathrm{~cm} \text { extruded } \\
\text { polystyrene (density } \\
10 \mathrm{~kg} / \mathrm{m}^{3} \text { ) Wall } \\
\text { thickness } 12 \mathrm{~cm}\end{array}$ & $\begin{array}{l}\text { Wall thickness } 12 \mathrm{~cm} . \\
+2 \mathrm{~cm} \text { Expanded polystyrene } \\
\left(\text { density } 10 \mathrm{~kg} / \mathrm{m}^{3}\right) \\
+ \text { Wall thickness } 12 \mathrm{~cm} .\end{array}$ \\
\hline R-value & 0.633 & 0.738 & 0.82 & 0.987 \\
\hline \multicolumn{5}{|c|}{$\begin{array}{l}\text { For the northern walls, the second modification } \mathrm{t} \text { is considered the most appropriate while } \mathbf{R} \text { - value }=\mathbf{0 . 7 3 8 .} \text { The } \\
\text { value required in the code } \mathbf{R} \text { - value }=\mathbf{0 . 6 9}\end{array}$} \\
\hline \multicolumn{5}{|c|}{$\begin{array}{l}\text { For the eastern and western walls the fourth modification is the most suitable for cost and Code requirements } \\
\text { where } \mathbf{R} \text {-value } \mathbf{0} \mathbf{0 . 9 8 7} \text { and the value required in the code } \mathbf{R} \text { - value }=\mathbf{0 . 9 0}\end{array}$} \\
\hline \multicolumn{5}{|c|}{$\begin{array}{l}\text { For the southern walls the second modification is the appropriate where } \mathbf{R} \text {-value }=\mathbf{0 . 7 3 8} \text { and the value required in } \\
\text { the code } \mathbf{R} \text { - value } \mathbf{= 0 . 7 0}\end{array}$} \\
\hline \multicolumn{5}{|c|}{$\begin{array}{l}\text { For Northeast \& Northwest walls and Southeast \& Southwest walls, the third modification is considered the most } \\
\text { appropriate while } \mathbf{R} \text { - value } \mathbf{0 . 8 2} \text { and the value required in the code } \mathbf{R} \text { - value }=\mathbf{0 . 9 0}\end{array}$} \\
\hline
\end{tabular}

Architectural Modifications of Roof: In terms of modifications with economical aspects and the Egyptian Energy code requirements for the roof, many trials have been tested in according to the thickness of the insulating layer of the roof by increasing the thickness gradually from $2 \mathrm{~cm}$. to $20 \mathrm{~cm}$. And, it is worth mentioning that when increasing the thickness up to be $8 \mathrm{~cm}$. The Rvalue $=2.675 \mathrm{~m}^{2}{ }^{\circ} \mathrm{C} / \mathrm{W}$ (Shown in the shaded part of table10), the increasing of thickness from $12 \mathrm{~cm}$. to $20 \mathrm{~cm}$. The increase in resistance ( $R$-value) has become slight and unnoticeable. So, it is recommended that the insulation layer to be ten centimeter polystyrene (density $15 \mathrm{~kg} / \mathrm{m}$ ${ }^{3}$ ), Where $\mathrm{R}$-value $=3.24 \mathrm{~m}^{2}{ }^{\circ} \mathrm{C} / \mathrm{W}$ and the value required in the code $\mathrm{R}$ - value $=2.80 \mathrm{~m}^{2}{ }^{\circ} \mathrm{C} / \mathrm{W}$ for the two models.

Table (10) Architectural Modifications Stage of Roof

\begin{tabular}{|c|c|c|c|c|c|}
\hline $\begin{array}{l}\text { Thickness of the } \\
\text { insulating material }\end{array}$ & $\begin{array}{c}\text { R-value } \\
\left(\mathrm{m}^{2} . \mathrm{C} / \mathrm{W}\right)\end{array}$ & $\begin{array}{c}\text { Thermal } \\
\text { loads } \\
\text { (KWH) }\end{array}$ & $\begin{array}{l}\text { Energy required } \\
\text { for cooling } \\
\text { (KWH) } \\
\end{array}$ & $\begin{array}{c}\text { Energy } \\
\text { reduction } \\
(\%) \\
\end{array}$ & Conclusion \\
\hline Without Insulating & 0.321 & 1701 & 2069 & non & \multirow{11}{*}{$\begin{array}{c}\text { The increasing of } \\
\text { thickness from } 12 \mathrm{~cm} \text {. } \\
\text { to } 20 \mathrm{~cm} \text {. has become } \\
\text { slight \& unnoticeable } \\
\text { on the R-values }\end{array}$} \\
\hline $2 \mathrm{~cm}$ Expanded polystyrene & 0.829 & 937 & 1286 & 35 & \\
\hline $4 \mathrm{~cm}$ Expanded polystyrene & 1.53 & 666 & 1040 & 52 & \\
\hline $6 \mathrm{~cm}$ Expanded polystyrene & 2.13 & 521 & 914 & 55 & \\
\hline $8 \mathrm{~cm}$ Expanded polystyrene & 2.70 & 424 & 846 & 58 & \\
\hline $10 \mathrm{~cm}$ Expanded polystyrene & 3.35 & 362 & 791 & 62 & \\
\hline $12 \mathrm{~cm}$ Expanded polystyrene & 3.94 & 309 & 775 & 64 & \\
\hline $14 \mathrm{~cm}$ Expanded polystyrene & 4.20 & 280 & 738 & 65 & \\
\hline $16 \mathrm{~cm}$ Expanded polystyrene & 5.12 & 258 & 730 & 65 & \\
\hline $18 \mathrm{~cm}$ Expanded polystyrene & 5.66 & 232 & 721 & 66 & \\
\hline $10 \mathrm{~cm}$ Expanded polystyrene & 6.25 & 215 & 700 & 67 & \\
\hline
\end{tabular}

Architectural Modifications of Openings: design of the openings depends on direction, proportion, ratio, material, and glazing. However, it is necessary to take into account the need for economy at the total cost, because the study is specific to the low-income sector. Therefore, the study is limited to openings design and solar Louvers for Minimizing solar radiation penetration by using architectural treatments fitted to the different building's facades and 
identify the required shading devices. A change in the type of glass and materials will not be addressed for cost savings-Hence; the openings were tested according to the code requirements. And it is worth mentioning the proportion of openings in the walls (WWR \%) of the sample study did not exceed $10 \%$. Simulation was carried out to increase the openings ratio to $30 \%$ (WWR \%), to illustrate the effect of the openings and their modifications on the thermal loads and the required energy for cooling, so as to be in parallel with the Egyptian Energy Code for residential buildings recommendations, which is provided for not to design openings ratio more than 30\% for eastern, southern and western façades. By achieving a minimum shading ratio of $90 \%$. Shading can reduce solar gains on the building facade, so effective shading strategies should aim at virtually preventing any direct solar radiation from entering the building, especially during the summer months. Shading reduces the effective solar heat gain coefficient (SHGC) of the glazing. This means that a cheaper glass with high SHGC can be used instead of high cost and lower SHGC of glass; as well shading also helps in reducing glare through the windows. Users tend to pull down interior shade if there is direct solar radiation on the glass; this negates all the benefits of day lighting, so Shading helps to ensure glare-free day lighting in the buildings. Note that the opening in the northern direction is the least influential; on the contrary opening in the western direction is most influential. Therefore, it is recommended to direct residential building spaces as living, reception and bed rooms to the northern direction, and service elements in south or west. Results of base case simulations indicate solar radiation on openings is the most important reason behind thermal gain, which requires design solar louvers according to

Figure (9) How to Design Solar Louvers

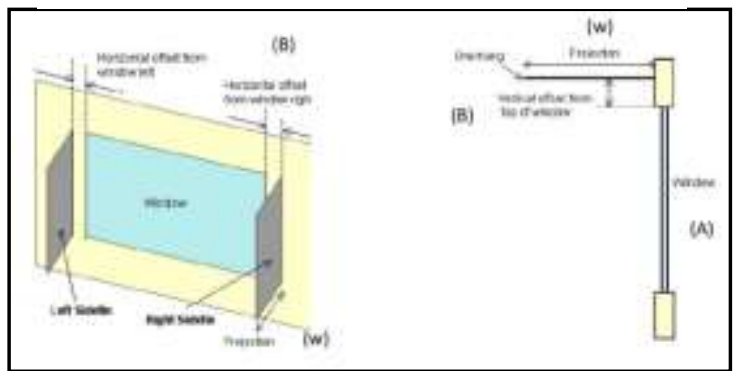
the Code rates, based on the determination of $P F=W /(A+B)$ values [Figure 9]. Architectural modifications of openings including openings ratio and shading devices of all kinds (horizontal, vertical, combination of both, and architectural blinds/shish), taking into account the characteristics of openings orientation, as following [Table 11].

Table (11) Architectural Modifications Stage of Openings

\begin{tabular}{|c|c|c|c|c|c|}
\hline \multicolumn{6}{|c|}{ Opening In The Eastern Facade } \\
\hline $\begin{array}{c}\text { Openings Ratio } \\
(10 \%)\end{array}$ & Without & $\begin{array}{c}\text { Horizontal } \\
\text { Louvers }\end{array}$ & $\begin{array}{l}\text { Vertical } \\
\text { Louvers }\end{array}$ & $\begin{array}{c}\text { Combination of } \\
\text { Both }\end{array}$ & $\begin{array}{c}\text { Architectural Blinds } \\
\text { (Shish) }\end{array}$ \\
\hline Thermal Loads & 445 & 328 & 412 & 279 & 118 \\
\hline Energy of Cooling & 1262 & 1218 & 1229 & 1148 & 1074 \\
\hline \multicolumn{6}{|c|}{$\begin{array}{l}\text { Energy required for cooling decreases with using architectural treatments, but rates are not high because the proportion of the openings is } 10 \\
\% \text {. The Code provides design openings ratio not more than } 30 \% \text { in eastern façades except by achieving a minimum shading ratio of } 90 \% \text {. }\end{array}$} \\
\hline $\begin{array}{c}\text { Openings Ratio } \\
(30 \%)\end{array}$ & Without & $\begin{array}{c}\text { Horizontal } \\
\text { Louvers }\end{array}$ & $\begin{array}{l}\text { Vertical } \\
\text { Louvers }\end{array}$ & $\begin{array}{c}\text { Combination of } \\
\text { Both }\end{array}$ & $\begin{array}{c}\text { Architectural Blinds } \\
\text { (Shish) }\end{array}$ \\
\hline Thermal Loads & 1089 & 828 & 910 & 592 & 257 \\
\hline Energy of Cooling & 1710 & 1490 & 1558 & 1420 & 1125 \\
\hline \multicolumn{6}{|c|}{$\begin{array}{l}\text { Based on the solar thermal gain coefficient calculated by the program and according to code requirements. Vertical Devices (50cm depth): } \\
\text { Primarily useful for east exposures to improve glass insulation value in winter by acting as a windbreak. }\end{array}$} \\
\hline \multicolumn{6}{|c|}{ Opening In The Southern Facade } \\
\hline $\begin{array}{c}\text { Openings Ratio } \\
(10 \%)\end{array}$ & Without & $\begin{array}{c}\text { Horizontal } \\
\text { Louvers }\end{array}$ & $\begin{array}{l}\text { Vertical } \\
\text { Louvers }\end{array}$ & $\begin{array}{c}\text { Combination of } \\
\text { Both }\end{array}$ & $\begin{array}{c}\text { Architectural Blinds } \\
\text { (Shish) }\end{array}$ \\
\hline Thermal Loads & 766 & 732 & 669 & 512 & 175 \\
\hline
\end{tabular}




\begin{tabular}{|c|c|c|c|c|c|}
\hline Energy of Cooling & 1491 & 1450 & 1412 & 1323 & 1110 \\
\hline \multicolumn{6}{|c|}{$\begin{array}{l}\text { Energy required for cooling decreases with using architectural treatments, but rates are not high because the proportion of the openings is } 10 \\
\% \text {. The Code provides design openings ratio not more than } 30 \% \text { in southern façades except by achieving a minimum shading ratio of } 90 \% \text {. }\end{array}$} \\
\hline $\begin{array}{c}\text { Openings Ratio } \\
(30 \%)\end{array}$ & Without & $\begin{array}{c}\text { Horizontal } \\
\text { Louvers }\end{array}$ & $\begin{array}{l}\text { Vertical } \\
\text { Louvers }\end{array}$ & $\begin{array}{c}\text { Combination of } \\
\text { Both }\end{array}$ & $\begin{array}{l}\text { Architectural Blinds } \\
\text { (Shish) }\end{array}$ \\
\hline Thermal Loads & 1889 & 1459 & 1450 & 1315 & 1106 \\
\hline Energy of Cooling & 2283 & 1929 & 510 & 505 & 164 \\
\hline \multicolumn{6}{|c|}{$\begin{array}{l}\text { Based on the solar thermal gain coefficient calculated by the program and according to code requirements. Horizontal Devices (35 cm depth) } \\
\text { to shade a window during summer, and allow sunlight to shine through a window in winter to help warm the inside of a building. }\end{array}$} \\
\hline \multicolumn{6}{|c|}{ Opening In The Western Facade } \\
\hline $\begin{array}{c}\text { Openings Ratio } \\
(10 \%)\end{array}$ & Without & $\begin{array}{c}\text { Horizontal } \\
\text { Louvers }\end{array}$ & $\begin{array}{l}\text { Vertical } \\
\text { Louvers }\end{array}$ & $\begin{array}{c}\text { Combination of } \\
\text { Both }\end{array}$ & $\begin{array}{l}\text { Architectural Blinds } \\
\text { (Shish) }\end{array}$ \\
\hline Thermal Loads & 999 & 834 & 917 & 1265 & 289 \\
\hline Energy of Cooling & 1804 & 1638 & 1721 & 1536 & 1298 \\
\hline \multicolumn{6}{|c|}{$\begin{array}{l}\text { Energy required for cooling decreases with using architectural treatments, but rates are not high because the proportion of the openings } 10 \% \text {. } \\
\text { The Code provides design openings ratio not more than } 30 \% \text { in western façades except by achieving a minimum shading ratio of } 90 \% \text {. }\end{array}$} \\
\hline $\begin{array}{c}\text { Openings Ratio } \\
(30 \%)\end{array}$ & Without & $\begin{array}{c}\text { Horizontal } \\
\text { Louvers }\end{array}$ & $\begin{array}{l}\text { Vertical } \\
\text { Louvers }\end{array}$ & $\begin{array}{c}\text { Combination of } \\
\text { Both }\end{array}$ & $\begin{array}{l}\text { Architectural Blinds } \\
\text { (Shish) }\end{array}$ \\
\hline Thermal Loads & 2280 & 1852 & 1394 & 1068 & 398 \\
\hline Energy of Cooling & 2881 & 2476 & 2408 & 1820 & 1377 \\
\hline \multicolumn{6}{|c|}{$\begin{array}{l}\text { Based on the solar thermal gain coefficient calculated by the program and according to code requirements. Vertical Devices (83 } \mathrm{cm} \text { depth): } \\
\text { Primarily useful for east exposures to improve glass insulation value in winter by acting as a windbreak. }\end{array}$} \\
\hline \multicolumn{6}{|c|}{ Architectural Modifications Stage of Openings Results } \\
\hline \multicolumn{6}{|c|}{$\begin{array}{l}\text { Vertical shading devices Protect from sun at the sides of the elevation for the east and western facades. Horizontal } \\
\text { shading protects from sun at high vertical angles and directly opposite to the wall to be shaded such as north and } \\
\text { south sides. Combination of horizontal \& vertical devices protect from sun in all orientations. }\end{array}$} \\
\hline \multicolumn{6}{|c|}{$\begin{array}{l}\text { A combination of vertical and horizontal shading elements commonly used in hot climate regions because of their } \\
\text { high shading efficiencies and because horizontal elements control ground glare from reflected solar rays. }\end{array}$} \\
\hline \multicolumn{6}{|c|}{$\begin{array}{l}\text { While the best shading type for optimum cooling energy savings is Shish, egg-crate, then vertical \& horizontal } \\
\text { shading. For NE and NW are need adjustable shading, but for SE and SW, planting is the best solution. }\end{array}$} \\
\hline \multicolumn{6}{|c|}{$\begin{array}{l}\text { Architectural Blinds (Shish) is considered to be one of the best treatments for window openings for the western, } \\
\text { eastern and southern facades, because it has a significant impact to reduce thermal loads resulting from solar } \\
\text { radiation on the openings. }\end{array}$} \\
\hline \multicolumn{6}{|c|}{$\begin{array}{l}\text { Code Specifications for louvers design is not enough to achieve the requirements of shading and reduce thermal } \\
\text { loads, which requires design using sun geometry method (HSA and VSA) }\end{array}$} \\
\hline
\end{tabular}

Analysis of the Simulation Outputs: Outputs of simulation analysis of the architectural modifications stage evaluate temperature and Heat Gain/Loss analysis for each zone inside the building, and in order to reach thermal comfort guided through the average value of the Predicted mean vote (PMV). Architectural modification stages including double skin wall thickness $12 \mathrm{~cm}$ for each, and $5 \mathrm{~cm}$ air cavity in between, using $8 \mathrm{~cm}$ expanded polystyrene for roof insulating, and design shading devices as the Energy Code requirements.

Model (East / West): Through study the lowest and highest Zone's temperatures in the hottest and coldest days, it was found that, the living room at the second floor reached its highest temperature of $31.5^{\circ} \mathrm{C}$ because of its western orientation of the external wall having window openings in west, while other zones temperatures ranged from $28-31.5^{\circ} \mathrm{C}$. Bed rooms at second floor reached its lowest temperature of $12^{\circ} \mathrm{C}$ although there are eastern openings, while other zones reached temperatures that range from $12-23^{\circ} \mathrm{C}$. And by comparing these results as recommended by the Egyptian Energy Code to achieve thermal comfort in the space, temperature must ranges between $21.8-30^{\circ} \mathrm{C}$. this confirms that this space is a bit far of thermal comfort at summer. While average value of PMV throughout the day ranges from 1.85-2.1 at summer, take into consideration living room at the second floor still facing higher temperature than other zones(sensation scale very hot), 
then bed rooms in the same floor. At winter, it was shown that most of zones located in comfort zone (sensation scale Neutral).

Model (North/ South): Through studying the lowest and highest Zone's temperatures in the hottest and coldest days, it was found that, bed rooms at the second floor reached its highest temperature of $31^{\circ} \mathrm{C}$ although it has northern orientation. This is because of the multi orientations of the external wall (north-east and west), then living room at the same floor for the south orientation reached $31.5 \mathrm{C}$. while other zones reached temperatures from $26-30^{\circ} \mathrm{C}$. Also bed rooms at second floor reached its lowest temperature of $18^{\circ} \mathrm{C}$, while other zones reached temperatures range $18-23^{\circ} \mathrm{C}$. And by comparing these results as recommended by the Egyptian code to achieve thermal comfort in the space, temperature must ranges between $21.8-30^{\circ} \mathrm{C}$. this confirms that this space is a bit far of the thermal comfort at summer. While average value of PMV throughout the day reached ranges from 1.9-2.0 at summer, take into consideration bed rooms at the second floor facing higher temperature than other zones (sensation scale very hot), then living room in the same floor. At winter, it was shown that most of zones are located in comfort zone (sensation scale Neutral).

Analysis of PMV for Two Models throughout the Year: Models values of feeling comfortable are not compatible with recommended indicators of PMV, temperature of the spaces compared with base case decreases after adding the modifications. However, the buildings is still far from the recommended temperature values, some spaces within two models are still far from thermal comfort ranges (sensation scale hot \& very hot); therefore PMV must be improved with next stage.

\section{Phase Ш: Improving the Efficiency of the External Envelope:}

In terms of modifications with economical aspect and Egyptian Energy Code requirements to reach thermal comfort values, it can be seen from the previous stage as an example, expanded polystyrene (EPS) for roof insulating is a difficult choice for thickness of insulating material and the lack of cost-saving. This requires alternative solutions for improving the efficiency of architectural energy saving as following architecture modification to walls, openings, and roof.

Architectural Modifications for improving the efficiency of walls: double skin wall thickness $12 \mathrm{~cm}$ each $\& 5 \mathrm{~cm}$ air cavity in between for the northern façade, double skin wall thickness $12 \mathrm{~cm}$ and $2 \mathrm{~cm}$ expanded polystyrene (density10 $\mathrm{kg} / \mathrm{m}^{3}$ ) for the eastern \& western facades, shown in [Table 9].

Architectural Modifications for improving the efficiency of openings: [Table11] indicates that Code Specifications for louvers design not enough to achieve the requirements of shading and reduce thermal loads, which requires design using sun geometry method (HSA \& VSA).

Analysis of the comparative study of louvers design modifications: Architectural Blinds (Shish) is the best treatment for openings at western, eastern
Figure (10) Comparative Study of Openings Modifications

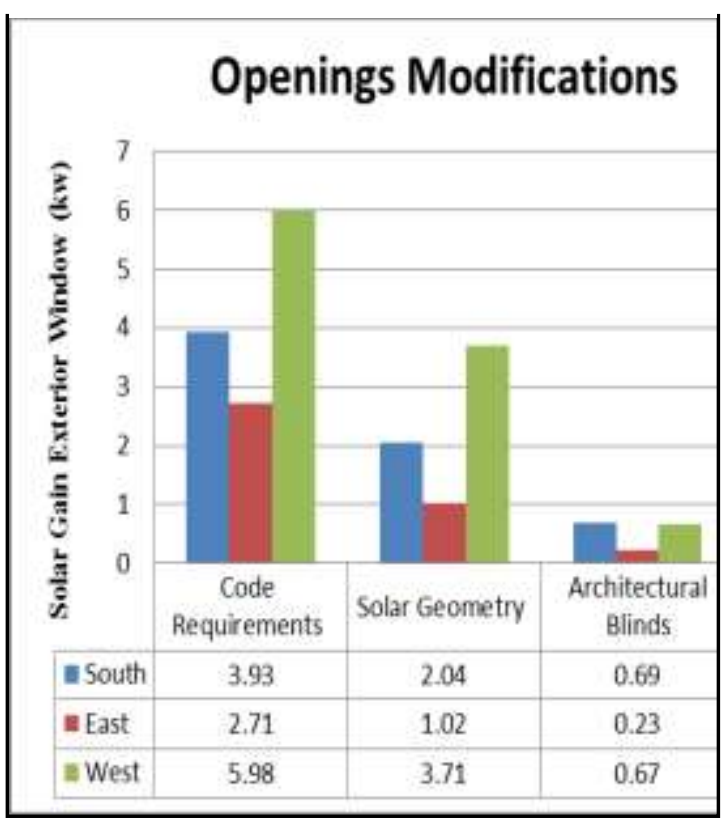


and southern facades, because of its significant effect on reducing the thermal loads resulting from the solar radiation on the openings, then designing louvers using solar geometry and then applying the Energy Code requirements [Figure 10]. The research recommends making adjustments on Code, where solar gain values are significantly reduced after design louvers using solar geometry (the vertical and horizontal shadow angles), where the percentage decline to half compared with Code rates. A combination of vertical and horizontal shading elements commonly used in hot climate regions because of their high shading efficiencies and because horizontal elements control ground glare from reflected solar rays.

$>$ Architectural Modifications for improving the efficiency of roof: There are many ways of roof treating with economical aspect in perspective including (Design wooden roofing shade as a Pergola supported by columns with attached structure for providing shade at $3 \mathrm{~m}$. height for reducing thermal loads and using the surface as a patio cover, design a shading system and 4 $\mathrm{cm}$. polystyrene (density $15 \mathrm{~kg} / \mathrm{m}^{3}$ ) for roof insulating, or designing rooftop farming with economical aspect, It should be noted that rooftop farming has an impact on increasing the economic return on the owner income. There are many systems that can be used to raise the roofs of houses, Soilless farming provide the best opportunity providing ideal conditions for low-income sectors. This requires a comparative study to choose the best alternative modification.

Analysis of the comparative study of roof modification: Thermal loads on the roof are clearly reduced; rooftop farming is the best modification for roof modifications Compared with the code requirements, adding $8 \mathrm{~cm}$ polystyrene $(15 \mathrm{~kg} / \mathrm{m3})$ as shown in [Figure 11]. There are

Figure (11) Comparative Study Roof Modifications for Case Studies

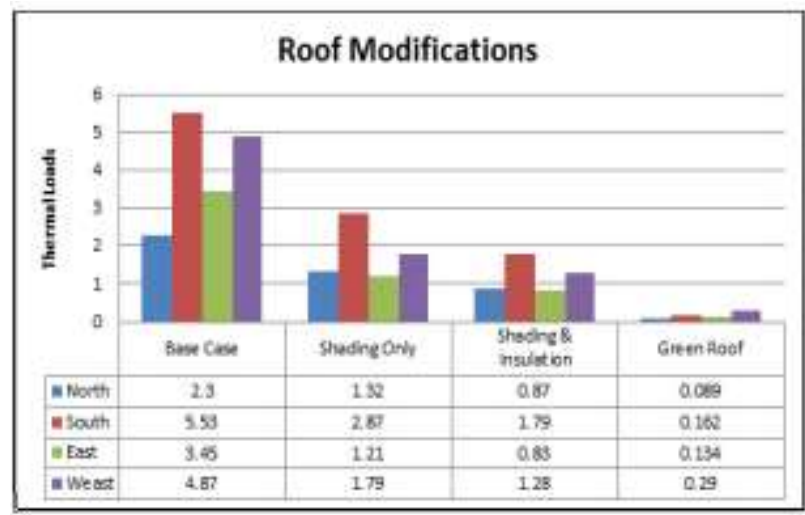
many benefits of green roofs including: architecture benefits (urban agriculture, improve public relations; transform dead space into garden space, expand roof life $2 \times 3$ times (up to 60 years); improve aesthetics), environmental benefits (provide green space, decree thermal loads; storm water management tool, energy savings; decreased waste; improved air quality, reduce airconditioning costs). It is worth mentioning; with rooftop gardens comes another environmentally friendly and booming initiative - urban agriculture. This involves using green roofs as miniature farms that actually produce a higher quality of food and lower grocery expenses.

Analysis of the Temperature of the Spaces According to Improving the Efficiency of the External Envelope: architectural modifications for improving the efficiency including: walls (double skin wall thickness $12 \mathrm{~cm}$ each $\& 5 \mathrm{~cm}$ air cavity in between for northern façade, double skin wall thickness $12 \mathrm{~cm}$ and $2 \mathrm{~cm}$ expanded polystyrene (density $10 \mathrm{~kg} / \mathrm{m} \mathrm{3}$ ) in-between for eastern \& western facades). For openings (design using sun geometry method (HSA \& VSA), and for roof (rooftop farming with economic aspect).Based on Stages of increasing architectural design \& energy efficiency through walls, roof, and opening modifications, and the 
differentiation between the best treatments to reduce thermal loads on different elements. In an attempt to reach the goal of reducing the temperature within spaces according to the lowest cost [Table 12, 13].

Table (12) Analysis of Temperature \& PMV According to Improving the Efficiency of the External Envelope

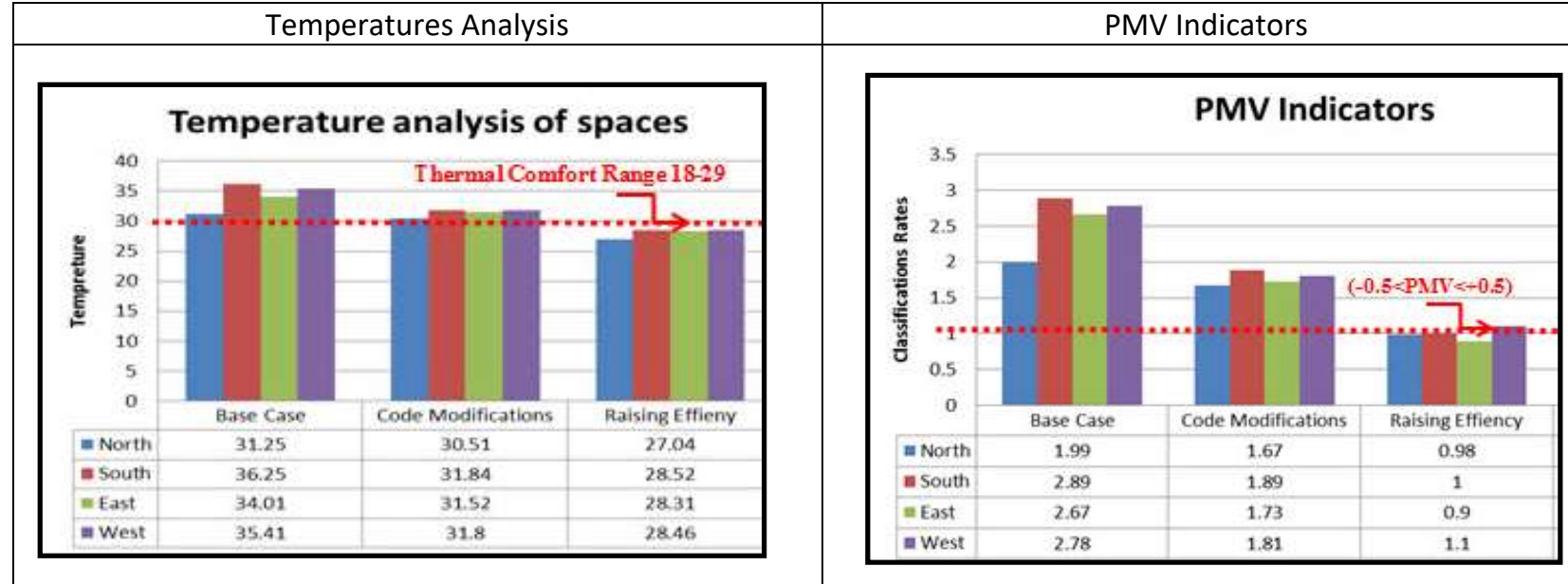

The temperature differed clearly in the three stages; The spaces are closer to the values of thermal comfort. ASHRAE 55 recommends that temperatures in range of $19-29^{\circ} \mathrm{C}\left(66-84^{\circ} \mathrm{F}\right)$. While the recommended acceptable PMV range for thermal comfort from ASHRAE 55 is between -0.5 and +0.5 for an interior space. Where Predicted Mean Vote sensation scale, value -3 (cold sensation)/ -2(cool)/-1(Slightly cool)/ 0 (Neutral) / 1 (Slightly warm)/ 2(Warm)/3(Hot).

Table (13) Temperature analysis for the two models throughout the year

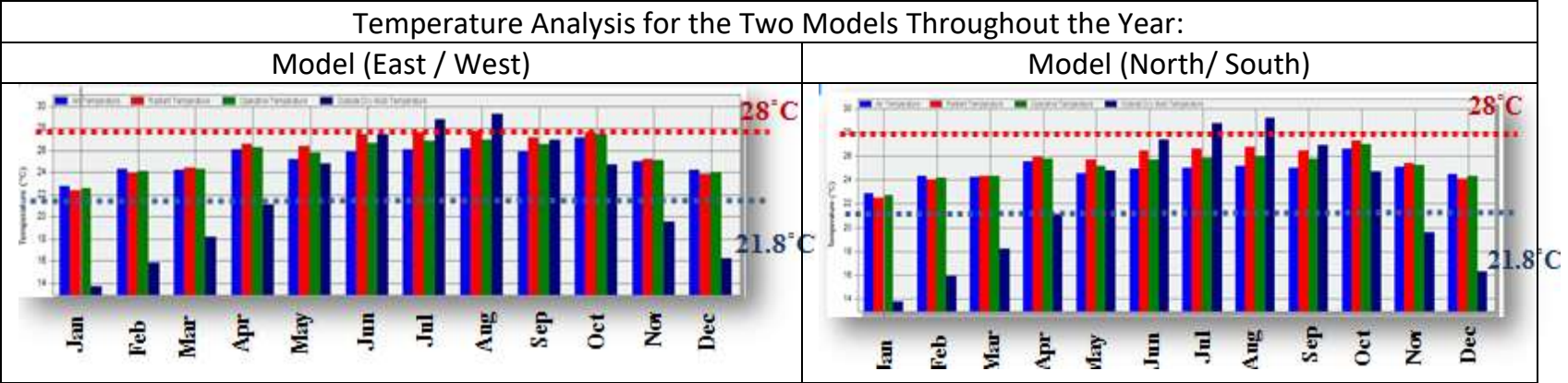

the average internal temperature of spaces are located in the comfort zone in all months of the year between 21.8 and 28 degrees, and there is a clear difference between internal and external temperatures, both in the most hot and coldest months of the year

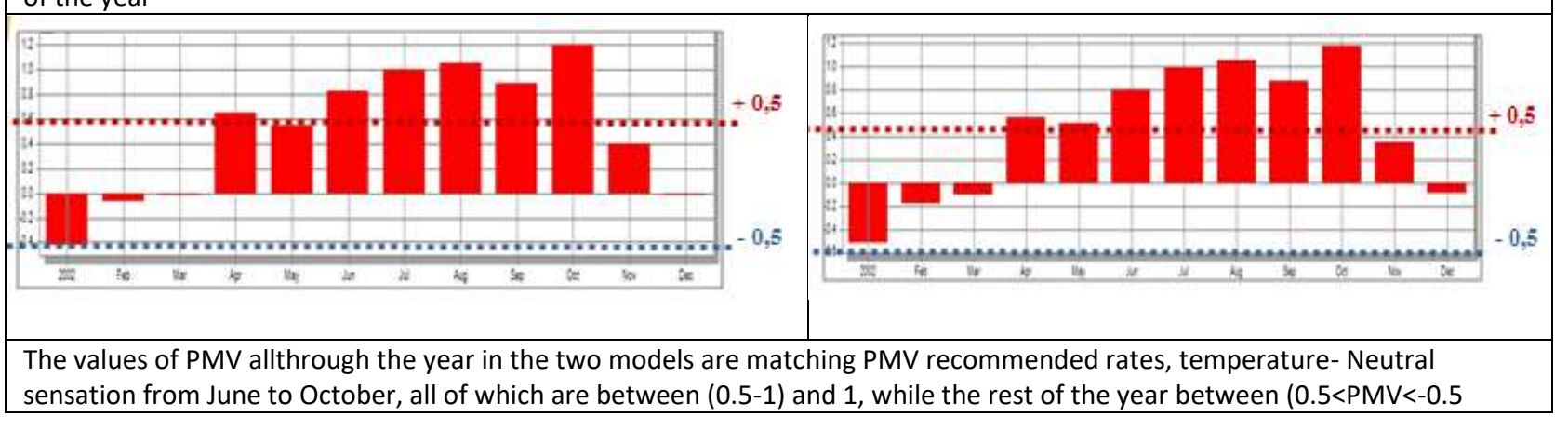

\section{Results and Recommendations:}

- Transforming Housing is about advocating for and supporting the development of solutions to solve this issue by: policy reform, development and advocacy, innovative project development, 
delivery support and evaluation, and research capacity building, embedded action research, research dissemination and influence.

- Transforming low-income housing for improving the efficiency of architectural energy saving design via improving the efficiency of the external envelope with economical aspect - for achieving a good environment respecting the social and cultural characteristics of the community- Towards advocate for housing that is affordable, well-located, diverse and welldesigned.

- Accessible and affordable energy efficiency would be transformative for low-income families who too often must choose between paying this month's energy bill or paying for food or medicine. More energy-efficient housing would translate into real savings for families and would result in healthier, more decent places to live.

- The planning process and the architectural procedures are both based on the socio-economic aspects involving community participation; this means that community participation is an important part in both the planning and architectural process.

- The current state of high temperatures for indoor environments in building your home project in New Beni-Suef City indicated that serious problems of discomfort generally exist in new housing projects in Egypt. The project acknowledges the severe shortage of affordable and appropriate housing options available to households on very low to moderate incomes.

- Results associated stages of increasing architectural design to provide energy efficiency as a tool for design, analysis and evaluate energy consumption of low-income housing via three stages: evaluate affordable housing projects, architectural modification stage, and improving the efficiency of the external envelope.

- In terms of modifications with economical aspect and Egyptian Energy Code requirements reaching thermal comfort values, architectural modifications for improving the efficiency of the external envelope with economical aspect. Wall modifications: double skin wall thickness $12 \mathrm{~cm}$ each \& $5 \mathrm{~cm}$ air cavity in between for the northern façade, double skin wall thickness $12 \mathrm{~cm}$ each and $2 \mathrm{~cm}$ expanded polystyrene (density $10 \mathrm{~kg} / \mathrm{m} \mathrm{3}$ ) in-between for the eastern \& western façades, openings modifications: Code Specifications for louvers design was not enough to achieve the requirements of shading and reduce thermal loads, which requires design using sun geometry method (HSA and VSA), roof modifications: rooftop farming with economic aspect. Architectural Blinds (Shish) is the best treatment for openings at the western, eastern and southern facades, because of its significant effect on reducing thermal loads resulting from the solar radiation on the openings to be followed by the design of louvers using solar geometry in accordance with the Energy Code requirements.

- It is recommended using fans to move air and reduce thermal comfort rates, when temperature is higher than 28 degrees to reach the required level of comfort and increase energy efficiency.

- Activation energy Code implementation in the field of construction, as well as restructure the code according to the latest energy efficiency criteria; update the code with materials, reformulate equations for calculating sun shading devices, and lovers design specifications. Study recommends reviewing Code specifications, for example: solar gain values are significantly reduced after design louvers using solar geometry (the vertical and horizontal shadow angles), where the percentage decline to half compare with Code rates. 
- Housing is NOT just a programmatic goal to be attained in a certain time plan, where adequate housing must provide more than four walls and a roof; but adequate housing as a component of the right to an adequate standard of living. On the contrary, Architectural design for lowincome housing is not energy efficient although social housing is one of the more housing sectors that need to raise energy efficiency, reach thermal comfort and reduce costs. Not just a dwelling is a message that low-income project citizen are always in need to improve quality and quantity of comfort levels. Accordingly, construction laws must be reviewed with taking into consideration the climatic aspects of each site to develop appropriate treatments for increasing the efficiency of architectural energy saving design.

\section{References}

[1] Daily News, (2010), Samih Sawiris on Low Income Housing, July 7, 2010. 'Closing the Infrastructure Gap: The Role of Public-Private Partnerships', a Deloitte Research Study.

[2] Shawkat, Y. (2014), EIPR Housing Policies Paper II Drafting a Fair Housing Policy for Egypt. EIPR Egyptian Initiatives for Personal Rights.

[3] Hussein, H., Darwish, N., \& Salem, E. (2014), IBNI BETAK: Not just a backyard, $6^{\text {th }}$ International Conference ACADEMIAARCHCAIRO: Responsive Urbanism in Informal Areas, Towards a Regional Agenda for Habitat II), Department of Architecture, Faculty of Engineering, Cairo University, Egypt.

[4] Soliman, A. M. (2012), The Egyptian episode of self-build housing, Habitat international, 36(2), 226-236.

[5] Ministry of Housing and Urban Communities, [Online], [Accessed 28 May 2018].Available at: http://www.moh.gov.eg/section3/Building materials.aspx

[6] Dorman, W. J. (2013), Exclusion and informality: The praetorian politics of land management in Cairo, Egypt: International Journal of Urban and Regional Research, 37(5), 1584-1610.

[7] El-Kabbany, M. F. (2013), Alternative Building Materials and Components for Affordable Housing in Egypt towards Improved Competitiveness of Modern Earth Construction, PhD, Ain Shams University).

[8] (NUCA), N. U., (2012), "Nabza 'an Ibni Batek (A summary about 'Ibni betak')".

[9] HBRC. Code: ECP 306-2005, The Egyptian Code for Enhancing Energy Use in Buildings: (unpublished work style), 1. Cairo, Egypt: Housing and Building Research Center (HBRC) 2006.

[10] Morrissey, J., Moore, T., \& Horne, R. E. (2011), Affordable passive solar design in a temperate climate: An experiment in residential building orientation. Renewable Energy, 36(2), 568-577.

[11] Ma, Z., \& Wang, S. (2009), Building energy research in Hong Kong: a review. Renewable and Sustainable Energy Reviews, 13(8), 1870-1883.

[12] ASHRAE. (2007), ASHRAE handbook-HVAC applications. Atlanta: American Society of Heating, Refrigerating and Air-Conditioning Engineers, Inc.; 2007.

[13] Bredenoord, J., Van Lindert, P., \& Smets, P. (Eds.). (2014). Affordable housing in the urban global south: seeking sustainable solutions. Routledge.

[14] R. El-Shamery, "The Impact of Climatic Conditions on the Urban Desert Communities in Upper Egypt [Assiut City As an Example of the New Applied", Master Thesis (unpublished work style), Department of Architecture, Faculty of Engineering, Assiut University, 2006.

[15] W. Sheta, S. Sharples, "A Building Simulation Sustainability Analysis to Assess Dwelling in a New Cairo Development", Fourth National Conference of IBPSA-USA, New York, 2010, pp94-101. 